\title{
Santa Maria Clays as Ceramic Raw Materials
}

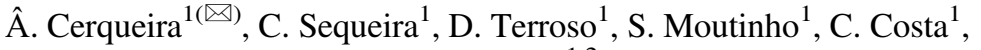 \\ and F. Rocha ${ }^{1,2}$ \\ ${ }^{1}$ GeoBioTec, Geosciences Department, University of Aveiro, \\ 3810-193 Aveiro, Portugal \\ angelamcerqueira@ua.pt \\ 2 RISCO, Civil Engineering Department, University of Aveiro, \\ 3810-193 Aveiro, Portugal
}

\begin{abstract}
There are evidences and records concerning clay exploitation for pottery in the island of Santa Maria (Azores, Portugal) in the past. Nowadays this activity is almost extinct but this is the only island in the archipelago with abundant residual and sedimentary clay deposits. To evaluate the applicability of clays from this island for modern ceramics, a campaign made in May 2017 allowed collecting twenty samples in several outcrops all over the island. All samples were subsequently analyzed in terms of granulometry, mineralogy, chemical composition and physical properties. Results revealed to be interesting, namely concerning mineralogical composition, where phyllosilicates such as Kaolinite are in high percentages. Granulometry also revealed that most part of the samples is composed by fine grain size particles $(<63 \mu \mathrm{m})$, which can be a good indicator of the existence of resources in great quantity.
\end{abstract}

Keywords: Santa Maria Island · Pottery $\cdot$ Physical characterization · Potentialities

\section{Introduction}

Santa Maria, the oldest and most oriental island from the archipelago, is very weathered, as consequence of intense volcanic activity alternated with sea level alterations and intense erosion episodes. There are residual and sedimentary clayey deposits in several parts of the island, one of which known as "Red Desert", corresponding to Feteiras Formation. In addition to the previous, Almagreira Formation is other important deposit of the island. These two in particular were more studied. The abundance of raw materials, gave this island an ancient tradition concerning exploitation of clays for pottery, being known as the "mother island" of clay. From this island, during centuries, white clays were extracted and exported to provide other islands. Recently a pottery oven was discovery "in the middle" of Vila do Porto and it date from the 18th century.

\section{Methods and Approaches}

Chemical composition was assessed by X-ray fluorescence, qualitative and semiquantitative mineralogical analyses were carried out by X-ray diffraction and crystallochemistry analyses were carried on a Scanning Electron Microscope (SEM) Hitachi

(C) The Author(s) 2019

S. Glagolev (Ed.): ICAM 2019, SPEES, pp. 311-312, 2019.

https://doi.org/10.1007/978-3-030-22974-0_74 
SU70 with Energy Dispersive X-Ray Spectroscopy (EDS) Brucker QUANTAX 400. Viscosity was assessed with a Haake Viscotester iQ. Plasticity Index was also computed from Atterberg Limits determination.

\section{Results and Conclusions}

Results are very positive since most part of samples are rich on phyllosilicates (69\% to $98 \%$, being kaolinite the most common), fine-grained, and showing adequate plasticity and viscosity. Geological formations, in particular Feteiras and Almagreira Formations, outcrops on a large part of the island, the residual ones showing always intensive alteration, therefore assuring the existence of good reserves.

Open Access This chapter is licensed under the terms of the Creative Commons Attribution 4.0 International License (http://creativecommons.org/licenses/by/4.0/), which permits use, sharing, adaptation, distribution and reproduction in any medium or format, as long as you give appropriate credit to the original author(s) and the source, provide a link to the Creative Commons license and indicate if changes were made.

The images or other third party material in this chapter are included in the chapter's Creative Commons license, unless indicated otherwise in a credit line to the material. If material is not included in the chapter's Creative Commons license and your intended use is not permitted by statutory regulation or exceeds the permitted use, you will need to obtain permission directly from the copyright holder.

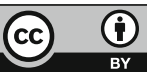

